\title{
Transformative Sustainable Business Models in the Light of the Digital Imperative-A Global Business Economics Perspective
}

\author{
Barbara Brenner \\ Department for Management and Economics, Danube University Krems, 3500 Krems an der Donau, Austria; \\ Barbara.Brenner@donau-uni.ac.at; Tel.: +43-2732-893-2100
}

Received: 14 October 2018; Accepted: 21 November 2018; Published: 27 November 2018

\begin{abstract}
The considerable body of literature on business models, business model innovation, and sustainable business models has yet to fully account for the impact of external dynamicsincluding the digital imperative - on generating sustainable value propositions. To address this issue, we developed a multifaceted framework of transformative sustainable business models, spanning three levels: the external environment, the organization, and the individual. We drew on the resource-based view and the literature on digitization to explain how organizations can capitalize on dynamic transformative capabilities to generate novel value propositions, based on both reconstructionist logic and shared-value logic. These include elements such as co-creation, usage-based pricing, agility, closed-loop processes, asset sharing, and collaborative business ecosystems.
\end{abstract}

Keywords: business model; shared-value; sustainable; digitization; Industry 4.0; innovation management; dynamic capabilities; transformation management; resource-based view; open-innovation; co-creation

\section{Introduction}

How can firms stay competitive in dynamic digital environments? How can business models be (re)conceptualized to successfully and sustainably address ongoing digital transformation? Striving for external alignment and adequate internal organizational response has become an ever-more complex task in times of digitization, with fast-changing environments [1-3]. A retrospective glance at the history of technology reveals that after tens of thousands of years of rather slow development, a number of ground-breaking ideas eventually led to programmable computing machines and seemingly-unlimited digital data-storage capacity, a development that poses major challenges to societies today [4]. Three times in the past 50 years, information technology radically reshaped competition and business strategy [5-7].

At the same time, business has been increasingly viewed as a major cause of social, environmental, and economic distress. While definitions of corporate sustainability vary [8], corporate ecological sustainability can be explained through the concepts of total quality environmental management, ecologically-sustainable competitive strategies, technology transfer through technology-for-nature swaps, and reduction of population impact on ecosystems [9]. Despite efforts to embrace corporate responsibility, the legitimacy of business has fallen: trust has diminished, and blame for societies' failures has been exacerbated. However, many companies continue with a narrow approach to value creation, focusing on short-term financial performance while ignoring broader influences that determine long-term success [10]. Instead of window-dressing peripheral social responsibility efforts, companies can respond to such challenges by putting sustainability at the core of their business model, thus creating shared value for the company, its stakeholders, and society as a whole [11].

Digitization has become widespread, affecting each aspect of the global economy [12]. Consequently, organizations are busy exploring how large-volume data—or "big data"—can be 
usefully deployed to create and capture value for individuals, businesses, and organizations [13-15]. Building off of machine learning and analytics that predict individual action (such as consumer choice), big data analytics go beyond analyzing patterns to attempting to predict the likelihood of events [16]. The catalytic impact of real-time data has led to an entirely new playing field for businesses, based on the huge volumes of user-generated data and decisions that are transferred and analyzed within and across various sectors [17-20]. Indeed, recent studies by Accenture and General Electric report that $85 \%$ of organizations believe that big data analytics will redefine the competitive landscape of their respective industries within the next three years [21]. Such an environment creates a myriad of opportunities for firms.

However, the digital revolution is a double-edged sword, since it entails not only a plethora of opportunities and benefits but also adds complexity, threats, and vulnerabilities to business and society [22]. The global economy is increasingly dominated by a few digital technological superpowers, who threaten to make business more monopolistic instead of more democratic as was originally assumed [23]. In addition, the multiplying chain-reaction effect of a single tweet or blog can cause profits or losses within a split second. In light of the vast potential benefits but also the significant vulnerabilities caused by the digital imperative, a sustainable development perspective argues that unintended rebound effects and critical tipping points ought to be managed carefully to establish resilient systems [4]. From a contingency theory perspective, organizational responses must match changing environmental conditions [24]. Leaders and managers must be able to grasp opportunities; craft novel, sustainable, value-creating schemes to capitalize on them; and reconfigure organizations and sometimes entire industries accordingly [25].

A dynamic global economy, with an ever-increasing velocity of technological advances, drives the creation of the latest innovative business models that use existing resources not only in smart and disruptive ways [26], but also in more sustainable ones [27,28]. However, it is still unclear how novel business models that mix and match services/products with ubiquitous data can generate new value propositions and evolve into viable, sustainable business models $[16,29,30]$. Although the ever-changing nature and environment of the digital economy has challenged traditional business concepts, little systematic scholarly inquiry has been conducted in the organizational research that explores the digital impact on organizations and essential business models [16,31]. If organizations restrain themselves from engaging in digital innovation, others will eventually capture the latent value [32]. While the depth and pace of innovation in the wake of the digital revolution has involved unprecedented speed, complexity, and multitude, new technologies seldom transform industries unless new business models emerge that match novel technologies to market needs [26,33]. Definitions of business models vary, but they quintessentially describe how a company creates and captures value [34-37]. In any given industry, a business model usually emerges over time and captures the most efficient way to allocate and employ resources to maximize value. However, occasionally, the dominant model is overturned by a new technology that, if adopted by the competitors, may become the new industry standard.

While research on both business models [38] and sustainable innovation [11,39] has been explored in academic literature, the way business models, dynamic digital technologies, and (sustainable) innovation interrelate has remained relatively unexplored [30,40]. A recent review of 681 papers on business models finds that the areas of innovation, change, and evolution are significant for the future development of the field [41]. Research on sustainable business models has seen a surge of interest in academia and practice, resulting in a number of Special Issues (e.g., Journal of Cleaner Production, Vol 45/April 2013, or Organisation and the Environment, Vol 29/1 2016) and review articles $[28,30,42-45]$ on this topic. However, research on sustainable business model innovation has only recently begun with attempts to define the field [44], and a more comprehensive understanding of its innovative nature is needed [46]. Specifically, research lacks an integration of the largely-separate bodies of literature on the digital economy $[47,48]$ and sustainable business models as well as 
an investigation of necessary organizational capabilities "to underpin strategies towards the circular economy based on digital technologies" (p. 11) [40,49].

The digital economy involves different challenges than the industrial economy for value-capture and innovation [31,47,48,50]. For example, Benner and Tushman [51] noted that "because of the shift of the locus of innovation some of our core organizational axioms will be fundamentally challenged by the digital revolution" (p. 2). While much progress has been made in advancing the business model concept, how companies change and develop their business models to achieve sustained value creation in dynamic environments is still poorly understood [52]. This paper aims to shed light on how external dynamics-notably, the digital imperative and the need for more sustainable resource employment-shape the transformative capacity and sustained value creation of business models. While innovative capacity is vitally important to the viability of business models, barriers to transformation are real, and change is hard to achieve [53]. Our aim is to advance the existing business model theory by conceptualizing transformative business models that are based on sustained value-creation and innovation while adhering to a shared-value logic. Drawing on the resource-based view, the shared-value approach, and contingency theory, we developed a multifaceted framework that helps to identify key elements of the transform2ative innovative potential of businesses models. We also ascertained that the varied individual, organizational, technological, economic, social, and environmental layers must be horizontally and vertically coherent. Our theoretical arguments integrate recent research findings on external dynamics (such as technological digital advances and rising global competitive dynamics) with internal capabilities on both the organizational and the individual levels, allowing for a more complete understanding of transformative sustainable potentials on the firm level.

This article is structured as follows. First, we briefly describe our methodology, synthesize findings from the literature review, and conceptualize a multifaceted framework of transformative sustainable business models. Second, we explore how external technological, economic, social, and environmental dynamics influence business models and shape value propositions. Third, we introduce the shared economic-societal value logic. Fourth, we turn to the organizational level and discuss the role of dynamic capabilities; transformative capacity; and organizational culture, structure, and strategy necessary to shape innovative sustainable value propositions. We also examine the individual level by exploring the transformative leadership potentials and digital mindsets of managers. Lastly, we critically discuss our findings and offer some avenues for future research.

\section{Methods}

This section discusses how a sustainable transformative business model was conceptualized, developed from a systematic review of academic literature and practical examples [54,55]. The methodology included three iterative steps: (1) identify themes and relevant categorizations from the literature [56]; (2) consider alternative categorizations and frameworks suited to define transformative sustainable business model; and (3) identify digital innovations from practice that impact traditional business models.

For the first step, a literature search on EBSCO Business Premier database and ISI Web of Science (Thomson Reuters New York) was conducted. We searched for terms in the title, abstract, and/or keywords (Boolean phrase, English, limited to peer-reviewed work and academic journals), including variations on terms, such as: business models, business model innovation, sustainable, digital, digitization, shared value, and transformative. While the query ("business models" and "digital") generated 689 hits, the majority of publications were published in information/library science or computer and information sciences, with only 285 business- or management-related articles. More refined searches (i.e., "business model" and "sustain" and "digit") generated 45 hits on the Web of Science and 36 hits on the EBSCO Business Premier database. Subsequently, the abstracts of the identified publications were scanned to define an initial sample of relevant literature. After a first quick content check, identified articles were either included or excluded from the analysis [54]. 
To maximize relevancy, we excluded purely computing and modeling research, as well as research from non-management fields [57]. To identify relevant articles and to build on (rather than replicate) the findings of a number of recent systematic review articles, we also required that the topic of business model innovation, digitization, and sustainability be dealt with in an essential way. This literature search generated articles on a research agenda for the circular economy and Industry 4.0 [40], sustainable business model archetypes [42,58], and canvas [27] or other conceptualizations-such as sufficiency-based business models [59], value migration [60], e-leadership in SMEs [61], success factors of peer-to-peer goods-sharing platforms [62], and a framework for analyzing the strategic potential of digitization in business model development, based on case-study evidence [63].

In a second step, formal keyword search techniques were followed up by "snowball" methods, pursuing references in references and using citation-tracking software. Abstracts of the additional publications were scanned to determine relevancy and were then either included or excluded from the analysis.

In a third step, given the immediacy of the topic, we also searched practitioner-oriented journals such as McKinsey Quarterly to gain some current insights on pressing issues caused by digitization in firms. Gray literature and practical examples were also collected to investigate how external dynamics, such as digitization, impact the transformative capacity of business models.

\section{Theory Development}

Although several decades old [64], the concept of business models gained popularity in the 1990s, triggering a vibrant scholarly discourse [34,37,38,65-69]. Several recent systematic review articles focus on different aspects in the area of business models, business model innovation, and sustainable business models; these were particularly helpful in carving out the gap in the literature. First, a review of 15 years of business model innovation covering 150 articles renders a critical assessment with respect to construct clarity, antecedent conditions, contingencies, and outcomes [70]. Second, a framework of sustainability-oriented innovation in SMEs based on 84 articles shows how distinct sustainability behaviors explain contingencies in types of innovation practices [71]. Third, a review of sustainable business models groups them into eight distinct archetypes [42]. Fourth, an overview of the emergence of the business model as a concept links it to sustainable innovation [30]. Fifth, a systematic review examines sustainable business model innovation [44]. Sixth, two reviews focus on the circular economy, one discussing organizational theory perspectives [72] and the other looking at supply chain configurations [73]. Seventh, an analysis of sustainable development and entrepreneurship has been conducted [74]. Lastly, a transdisciplinary systematic literature review on environmental sustainability and IT-enabled business transformation covers 12 disciplines across six core categories and presents a transdisciplinary framework for business transformation [75]. The majority of these systematic reviews critically comment on the non-accretive nature of the literature on business model/business model innovation, which fail to converge on definitions and frameworks for normative or predictive findings $[57,70]$.

A business model is described as a model [76], as an organizational characteristic [34,38], or as having a reduced scope to achieve certain means [77]. Several review articles and Special Issues (i.e., Long-range planning 2010 43/2-3 and 2013 46/6) on the topic synthesized the current state of debate $[41,69,70,78]$. The notion of innovation in business models is often coined as "business model innovation", which "complements the traditional subjects of process, product, and organizational innovation" [69] (p. 1032); this explanation lacks construct clarity and is not well understood [70]. Nevertheless, Amit and Zott [49] proposed "the business model construct as a unifying unit of analysis that captures value-creation arising from multiple sources" (p. 494).

Technologies and business models interact regularly [79], and we know that technological innovation influences performance [80]. Digital technology creates a new form of knowledge that provides essential complementary insights (that cannot otherwise exist) into complex innovation [81]. Similarly, the Internet of things changes business models [82]. In their Digital Economy Outlook 
2017 [83], the OECD observed that information and communication technologies (ICT) are transforming data-driven innovation, business models, and social interactions, and that the full potential of the digital economy has yet to be realized. Hence, we need a more precise understanding of how innovation links to performance through the business model [79], and which organizational resources and capabilities are necessary to enabling sustainable value propositions based on digital technologies [40].

To determine the potential parameters of sustainable transformative business models, we need to examine both external dynamics in the business environment as well as internal organizational determinants. Building on contingency theory, transaction cost theory, the resource-based view, and shared value-logic, we propose a multifaceted framework of sustainable transformative business models. Figure 1 gives an overview of the multiple layers encompassed in sustainable transformative business models. Given that the individual, organizational, social, economic, technological, and environmental layers of transformative business models are highly intertwined, they are ideally both horizontally and vertically coherent. While single components of each layer must be inherently consistent, vertical alignment across the three layers supports a more robust holistic, system-level perspective on sustainability-oriented innovation [27,69]. Figure 1 illustrates vertical and horizontal coherence of organizational, economic, and environmental layers. Next, we address all these determinants in some detail, layer by layer.

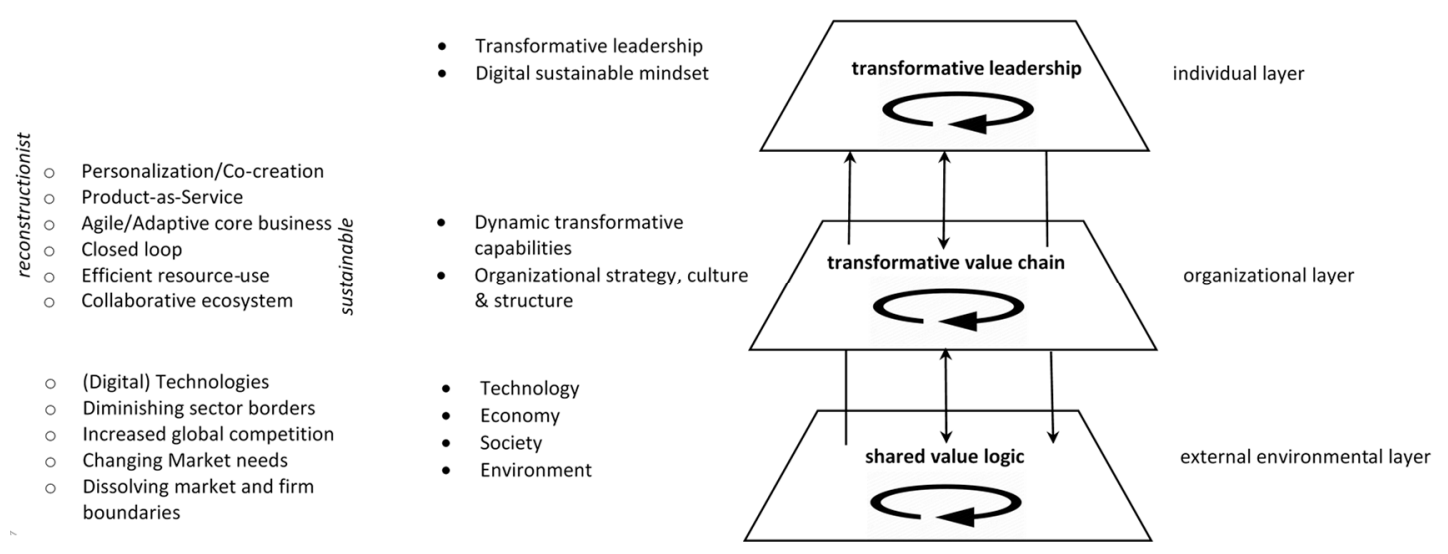

Figure 1. Sustainable Transformative Business Models.

\subsection{External Environmental Layer}

\subsection{1. (Digital) Technology}

Mobile computing, cloud computing, big data, and the Internet of Things are key technologies in Industry 4.0 [84-86]. Over the past decades, a pipeline of technological developments-in particular, information and communications technologies (mobility, cloud, and data analytics) and material technologies (sensors, new materials, and new molecules)—spurred technological advances and fueled productivity and growth across industries $[87,88]$.

Sensing, Interfacing, and Augmented Reality

The development of sensors allows for a broad, cost-efficient capture of data [26,89]. By 2020, some 50 billion smart devices will be connected; together with billions of smart sensors, this will create a global supply of data that is expected to at least double every two years [90].

However, a large disconnect persists between the wealth of digital data available and the range of application in the physical world. Augmented reality-a set of technologies that allow digital data and images to be portrayed on the physical world and to act as an interface between humans and machines-may help to close this gap via smart, connected products [91]. At its core, augmented reality transforms large volumes of data and analytics into images or animations that overlay onto the real world. For example, an application in vehicles allows for navigation, collision warnings, and any 
other relevant information directly in the driver's line of sight. People will no longer be required to mentally convert 2-D information into a real-world 3-D context. This technology has the potential to reshape how we learn, make decisions, and operate. Implications for business are staggering, since augmented reality would "transform how enterprises serve customers, train employees, design and create products, and ultimately how they compete" [91] (p. 48). Thus, smart, connected products and services proliferate, value-creation is amplified, value-chains are disrupted, competitive dynamics are aggravated, and industry boundaries are reshaped [7].

\section{Optimization Technologies}

Big data, artificial intelligence, and machine learning enable vast amounts of unstructured data to be turned into rules, dependencies, and decisions [92]. Business, engineering, and finance already draw on huge libraries of intelligent functions. Social media platforms and related web resources offer a vast and readily-accessible depository of individual data and enable activities, attitudes, and personal information to be tracked at unprecedented scale and depth [93]. While this virtual realm offers a level of intimacy regarding opinion and social interaction, dealing with "big data" raises not only ethical issues but also questions relating to the expertise required to gather, analyze, and interpret this data. A steep methodological learning curve calls for bridging disciplinary boundaries and engaging in collaborative cross-disciplinary work, which requires computer scientists and associated IT specialists to team up with social scientists to make adequate sense of big data [94].

Some argue that digital technologies have already created a virtual and autonomous economy that provides external intelligence in business [95]. Access to large datasets often determines market valuations of corporations [60]. However, algorithms need to be carefully checked for potential bias, as sadly shown by the case of a risk-assessment software, which made false predictions about black and white defendants [96].

\section{Digital Platforms}

Platform businesses that directly connect producers and consumers have devoured market share and transformed the nature of competition. Understanding the dynamics of platforms and ecosystems is vital in the digital economy [47]. While platforms have existed for years, information technology has drastically diminished the need to own physical infrastructure and assets. Based on external developer systems, Google, Apple, and Microsoft became the most valuable companies as of 2015 [86]. Traditional business models are under pressure to learn how to benefit from such platforms [97]. For example, how did Apple, with a market share of less than $4 \%$ in 2007, overrun dominant incumbents in the cellular phone industry by exploiting the new strategic options provided by platforms? The chief assets forming the basis of competitive advantage and value creation of platforms are information and interactions. Apple understood this early on and accordingly configured the iPhone as a connecting tool for app developers and app users [98]. Although platforms come in varied forms, they essentially comprise four players: owners who control their intellectual property, providers that serve as user interfaces, producers that offer their products/services, and consumers who use these offerings. Platforms redefine corporate strategies by shifting the focus from controlling to orchestrating resources, from optimizing internal processes to facilitating external interactions, and from enhancing customer value to optimizing ecosystem value [97].

Traditional businesses do not gain more commensurate value after a certain number of consumers is reached, because the value-creation curve typically flattens out with increasing consumers; however, many platform businesses become more valuable the more that people and/or companies use them, connect with one another, and create network effects [23]. Hence, with increasing participants on both sides of the market, the value-known as "the network effect" - soars. Moreover, consumers and producers can easily switch roles in generating value for platforms [99]. At the same time, hub firms increasingly create and control essential connections, using their customer base to aggressively move into new sectors that were once considered separate industries. For example, Alibaba spin-off Ant 
Financial does not offer any financial service that is superior to what other institutions already provide, but it builds on the data from Alibaba's existing user base to commodify traditional financial services on their digital platform. Similarly, Google moved from search engine into mapping, mobile operating system, driverless cars, and voice recognition.

The emergence of digital hubs can be explained by three principles of digitization and network theory: First, Moore's law postulates that computer processing power will double every two years [100]. Second, Metcalfe's law states that the value of a network increases proportionally with the number of nodes or users ("network effect") [101]. Third, Barabási's notion that digital network formation naturally leads to positive feedback loops that reinforce increasingly highly connected hubs [23]. Once a hub is highly connected in one industry it can leverage this advantage by spreading out into new sector, such as Ant Financials did. Domino effects can be observed in many sectors from telecommunications, music, E-commerce, and are currently accelerating into brick-and-mortar industries, such as the automotive sector.

However, value generated by hub networks is subject to competition, innovation and responses by the user community and regulatory pressures. Multihoming, a practice where participants use various hubs simultaneously, can considerably mitigate hub power. Drivers as well as passengers routinely multihome across different ride-sharing platforms, and scout for the most beneficial deal before using a specific hub. At the same time, companies tend to make their products and services available on multiple hubs to avoid being held hostage by single dominant players. Given the pace of change and competitive pressure, platform leaders must continually innovate and redesign their business models [102]. Thus, three types of dynamic capabilities are critical for platform leaders, namely innovation capabilities, environmental scanning and sensing capabilities, and integrative capabilities for ecosystem orchestration [103].

\section{Mobility and Cloud Technology}

Mobile cloud computing executes mobile applications on resource providers that are external to the mobile device [104]. It provides a tool to the user irrespective of his/her movement or location, and thus the user can continue his/her work seamlessly while being utterly mobile. Cloud computing encompasses applications delivered as services over the Internet as well as the hardware and systems software in the datacenters that provide the service. It has allowed developers to deploy their innovative ideas for Internet services without any large capital outlays in hardware or other expenses. The ability to render fast-paced development without worrying about wasting costly resources-or under-provisioning a service that may become unexpectedly popular-and to allow for quick results of large batch-oriented tasks makes for an elasticity of resources without charging a premium at a scale unprecedented in the history of IT [105].

\section{Decentralized Small-Scale Manufacturing}

Advanced manufacturing technologies, coupled with consumer demands for more customized products and services, have led to shifts in scale and distribution in manufacturing [106]. Additive manufacturing, or 3-D printing, is clearly part of the digital/industrial transformation. It allows organizations to be disruptive by producing what they want, where they want, and at what scale they want. Essentially, it permits getting leaner and cleaner, and becoming more global by actually becoming more local. A more cost- and resource-efficient small-scale production can have a positive impact on a firm's competitiveness. A literature review on additive manufacturing and its societal impact clearly points towards a promise of reduced environmental impact for manufacturing sustainability [107]. Moreover, additive manufacturing can improve resource efficiency, enable closed-loop material flows, and realize synergies across the product and material life cycles [106]. 


\subsubsection{Economy}

\section{Diminishing Sector Borders}

Traditional industry boundaries are being radically reordered by digitization [108]. Digital native organizations are difficult to fit into traditional industry frameworks. For example, Rakuten Ichiba, Japan's single largest online retail marketplace, also provides e-money that is usable in hundreds of virtual and real stores; issues credit cards; offers financial products and services, including Japan's largest online travel portal; and provides an instant messaging app—Viber-used by 800 million users worldwide. Organizations such as these are neither defined nor constrained by traditional sector boundaries. While we may argue that industry boundaries have always been fluid, because disruptive technological innovations cause sectors to emerge, disappear, or merge, the digital revolution has certainly accelerated these dynamics [47]. If the friction of transactional costs is reduced, and unprecedented large amounts of electronic data are provided, along with omnipresent mobile interfaces and artificial intelligence, then customer expectations are reshaped and distribution is redefined. At the same time, customer-centric, unified value propositions allow for co-creation and for value-chains to be bridged in unprecedented ways.

Information technology is also revolutionizing products. Products have become more complex, combining hardware, sensors, data storage, microprocessors, software, and more in a myriad of new ways [98]. Such smart, connected products fundamentally alter industry structures and the nature of competition, and they raise new sets of strategic choices, such as how value is created and captured, how relationships with traditional partners are (re)defined, and how company roles need to change [7].

Managers seem aware of the potential threats caused by cross-sector dynamics. A recent survey by McKinsey shows that one-third of the 300 managers interviewed from 37 different industries are worried that competitors from other sectors are gaining clearer insights into their customer base [108]. While this new environment will certainly not change everything, boundaries between industry sectors will continue to blur and play by novel rules that call for different organizational capabilities. Consequently, defending one's position in a certain industry will be still critical, but so will capturing opportunities across sectors before others get there. That means that companies will need to (re)define their business models to effectively compete in rapidly-emerging arenas of business opportunities, where competition derives from dimensionally-different sectors. Such arenas are sometimes described as "digital ecosystems" that are highly consumer-centric, providing an end-to-end experience for a wide range of products/services through single-access gateways regulated by contracts [108]. A case in point is China's three Internet giants, Baidu, Alibaba, and Tencent, which have built a rich digital ecosystem that is now spreading beyond them [109].

\section{Increased Global Competition}

The expansion of international trade has led to greater specialization on a global scale, which requires firms to make a global system of vertical specialization and bilateral dependence succeed by combining and reconfiguring parts of the global value chain in search for novel joint solutions [25].

New technologies drive global competitive dynamics by enabling new digital ventures, and vice versa. Sustained competitiveness in a global marketplace calls for a continuous and rapid innovation that is difficult to achieve and sustain [110]. For example, China has become a leading force in several areas of the digital economy over the last decade and is home to powerful digital innovators with global reach, such as Baidu, Alibaba, and Tencent. The Chinese government has actively encouraged digital innovation by investing globally in the latest technologies and by giving innovators plenty of room to experiment and to shape a digital infrastructure later [109]. In e-commerce, China accounts for more than $40 \%$ of worldwide transactions; mobile payments related to individual consumption account for US $\$ 790$ billion in value, 11 times that of the US [109]. Cross-border accelerator programs, such as FORGE (a joint UK-China initiative), foster incubation of early-stage tech start-ups and expedite international innovation dynamics [111]. 
While digital technology enables growth in value across the economy, the value captured is becoming more skewed and concentrated in the hands of a few globally-powerful hub firms. For example, Google's Android technology forms a bottleneck through which other product and service providers must leverage their power by using the network-based assets they employ to create scale in one setting and to transfer them to another industry. Consequently, adjacent industries may get locked into a vicious cycle of competitive dependencies [23].

At the same time, internationally-operating venture capital firms play an ever-increasing role in innovation by providing capital to firms that typically possess few tangible assets and operate in rapidly-changing markets [112].

\section{Changing Market Needs}

On a worldwide scale, a stable increase in demand (based on the steady progress of emerging economies) is accompanied by a greater fragmentation in consumer preferences. A combined upturn of economic growth in major regions and sound corporate profits are boosting business confidence and investment propensity. Despite reductions in 2015, commodity prices did strengthen and underpin a recovery in developing countries in 2017 [113]. These developments give momentum to more sustainable and environmentally-benign resource employment. Therefore, demand is rising for eco-efficient and effective innovations that help conserve and improve natural, social, and financial resources and that embrace stakeholder involvement [27].

Firm-level innovation depends on external contexts, including domestic and local institutions such as the supply of skilled workers, universities, financial institutions, the legal system, regulatory and standard bodies, government and judiciary, supply base, and presence of related and/or comparable industries [114,115]. A recent analysis based on evidence from 125 countries in 1997-2013 shows that the strength of a national innovation system, rather than participation in global value chains, still drives economic growth [116]. As a result, developing a national technological building capability may enhance successful exploitation of foreign knowledge and therefore economic progress [117]. At the same time, heightened environmental regulation increases pressure on firms for more sustainable and innovative business models.

\section{Dissolving Market and Firm Boundaries}

Along the lines of dismantling sector boundaries, market-firm boundaries are also being increasingly redefined [118]. According to Coase [119], firms establish their boundaries based on transaction costs (TCE). Essentially, Coase's logic dictates that a company performs the focal activity in-house only when the cost of market transactions for products or services exceeds the cost of coordinating and managing all incremental activities needed to produce that product or service within a firm ("hierarchy"). Digitization, however, reduces transaction costs and facilitates contracting activities out, leading to sophisticated networks of specialized market relationships [108]. Firms based on platform ecosystems, such as Apple or Google, moved their locus of value creation from inside the firm to outside of it. These firms capitalize on an external developer ecosystem, which not only inverts the firm but also allows for enhanced profitability based on high-risk innovations that are made possible with a large number of external developers [86]. Such networks triggered by dissolving firm boundaries make it easier to meet rising customer expectations.

Advanced analytics, maturing artificial intelligence, and an ever-present mobile Internet has led consumers to expect fully personalized solutions. Organizations that act as orchestrators of networks (i.e., by linking potential consumers to potential producers) can capitalize on adding value by predicting consumer needs before they are even articulated. On the other hand, digitization lowers switching costs for consumers and increases price transparency, potentially shifting the balance of power towards consumers. Haier, the world's leading white-goods manufacturer, drastically disrupted its organizational structure around platforms in order to create entrepreneurial teams within the firm that interact directly with users/customers and their needs [120]. 
Similarly, as the global sources of invention and innovation have dispersed, even very large firms cannot continue to rely entirely on their internal R\&D. Declining costs of computing and communications have facilitated collaboration with suppliers and other players in the market ecosystem, increasing viability for open innovation [65]. Open innovation allows firms to identify and exploit new technological capacities developed both inside and outside firm boundaries [32]. The "lean startup" idea grasps at the very essence of customer centricity; it favors experimentation over elaborate planning, customer feedback over intuition, and iterative design over traditional up-front desktop design. Concepts such as "minimum viable product" or "pivoting" spread quickly and tend to bring the customers into the product/service design from the very beginning [121].

\subsubsection{Society and Environment}

Externalities occur when firms create social costs, i.e., pollution, that they do not bear. Traditionally, societal institutions counteract this by imposing taxes and regulations so as to "internalize" such costs. This vantage point often led to corporate strategies that largely excluded social and environmental considerations from their business models. The principle of "shared value", as introduced by Porter [10,122], is a novel way of achieving economic success that recognizes how societal and economic needs define markets and that couples economic value with societal value. Essentially, it includes policies and practices that advance a firm's competitiveness while simultaneously advancing the economic and societal conditions of the community in which it operates. The competitiveness of the firm is intertwined with the conditions of its surrounding community; a business needs a successful community-whether a virtual one or a real one — to create demand for its products, and it in turn provides jobs and wealth creation for its citizens. In particular, social harms or weaknesses frequently cause internal costs for firms, such as wasted energy/resources or remedial training to compensate for inadequacies in education. At the same time, addressing societal constraints may not necessarily augment corporate costs but instead enhance productivity, through innovative operation methods, management approaches, or entire business model disruptions. Firms can create shared value by reconceiving products and markets, redefining productivity in the value chain, and building supportive industry clusters. A shared-value perspective does not focus on redistributing value as the fair trade model does, but on expanding the overall value created. Studies with cocoa farmers in the Cote d'Ivoire show that, while fair trade enhanced their income by $10-20 \%$, shared value investments-including improved growing techniques and a cluster of supporting and related industries-can boost their income by $300 \%$ [10]. Therefore, transformative sustainable business models must adopt a shared-value approach that encompasses their social and environmental surroundings. This is in line with the literature on sustainable business models, which describes business models as extending beyond the immediate entity of the firm, such as shareholders and customers, to include value captured for key stakeholders $[42,69,123]$. Schaltegger et al. [11] proposed a typology of defensive, accommodative, and proactive business model innovations.

\subsection{Organizational Layer}

At the organizational level, the focus is on the firm, its capacities to develop new technologies, and how to connect these in order to generate new value propositions. However, existing research on sustainable innovation often treats the firm as a black box [30,124], when "the firm is a central actor for the effectuation of innovation and technological change" [25] (p. 680). Consequently, we set out to scrutinize organizational-level capabilities, organizational strategy, culture, and structure as the foundations of transformative action and innovation.

\subsubsection{Dynamic Transformative Capabilities}

Digital transformation seems to be impeded by a lack of vision or sense of urgency in some companies, while in others it is impeded by culture and organizational constraints [19]. The MIT Technology review [125] published a list of 50 companies that created new business opportunities by 
combining innovative technology with savvy business models. While this list contained the usual suspects, such as Apple, GE, and IBM, it was full of ambitious startups, e.g., SpaceX (creating reusable rockets for space travel), Nvidia (providing processing power for AI software), Face++ (pioneering face-recognition technology), and Carbon and Desktop Metal (additive manufacturing). By analyzing the transformative and sustainable potentials of business models, we attempted to unveil some of their common underlying key elements of success.

Dynamic capabilities include a firm's ability to integrate, build, and reconfigure internal and external resources to address and shape rapidly-changing environments [3]. These include all skills, procedures, and organizational structures that firms use to create value. While such capabilities may be rooted in certain change routines and analyses, they are generally based on creative managerial and/or entrepreneurial acts that are aimed at matching internal competences with opportunities in the business environment. Critical to its innovative capabilities is a firm's "ability to recognize the value of new, external information, assimilate it, and apply it to commercial ends" [126] (p. 128), a concept labeled as "absorptive capacity". As organizations grow, their capabilities are embedded in competences/resources that are essentially shaped by organizational values. These in turn define the implicit norms and rules in organizations, ultimately determining how priorities are set.

The resource-based view (RBV) of firm building from Penrose [127] and others [128-130] theorizes that a firm earns rents by leveraging its unique resources, which in turn give rise to the analysis of learning and knowledge management as the means to create novel, hard-to-imitate resources. A firm's resources are tacit to varying degrees, including knowledge and intellectual property, and they are significant sources of competitive advantage. Since they are more of a stock than a flow, they need to be constantly renewed [131]. This need for renewal is amplified in light of the digital imperative. The capability lifecycle depicts a set of possible paths that characterize the evolution of an organizational capability [132]. Essentially resources/competences and dynamic capabilities must be established internally and cannot simply be acquired externally. As a result, sensing (identifying assessment of an opportunity), seizing (mobilizing resources to address an opportunity and to capture value from doing so), and transforming (continued renewal) are attributes that in particular enable firms to (co)evolve with the business environment [133]. While almost every company recognizes the potential for using digital technologies to achieve transformation, most are still unclear on how to get results [19]. This may be due to a lack of dynamic capabilities and path dependencies, since the ability to utilize outside knowledge is largely a function of the level of prior related knowledge within the firm [126]. However, sensing and seizing are similar to two other activities that are prominently discussed in management literature as incompatible inside a single organization, namely, exploration and exploitation [134]. These two types of activities require different management styles and are therefore rarely found within one firm, except for an ambidextrous organization where two separate sub-units with distinct cultures are linked [135].

Transformative capacity is a seminal capability required to create and capture (future) value. Empirical research on how firms can continuously create value is scarce. A notable exception is the work of Achtenhagen [52], who identified three critical capabilities: an orientation to experimenting with and exploiting new business opportunities; a balanced use of resources; and coherence among leadership, culture, and employee commitment as the basis for sustained value creation. Firms need to periodically (re)consider their own "fit" to the arising opportunities they plan to exploit [25]. However, commitment to existing path dependencies, processes, and assets makes this hard to do, especially if a firm performs satisfactorily.

In innovation studies, a consensus is emerging that the role of the business model in fostering innovation is twofold. First, business models can be vehicles for innovation by connecting innovative products and technologies to realized market outputs. Second, they can be a "source of innovation in and of itself" [67] (p. 420). Quintessentially, sensing and seizing show a path for creating value, but firms still need to periodically (re)consider their own fit with newly-arisen opportunities. A review of sustainable innovation in SME showed that higher-order capabilities 
and interaction with external actors led to more radical sustainably-oriented innovations [71]. Our conceptualization suggests that sustainable transformative business models need to adhere to two sets of logics: reconstructionist/disruptive logic, in the sense of creating blue oceans [136] and shared value/sustainable logic.

\section{Reconstructionist Elements: Personalization \& Co-Creation-Usage Based-Agility}

Organizations can disrupt markets and gain a competitive edge by leveraging digital technology towards creating unique service and/or product offerings that allow for a personalized customer experience. Based on insights from "big data", value propositions can be revamped and/or specifically tailored in real time. Transformative firms often take advantage of technology to achieve product and/or service offerings that are personalized and tailored to individual needs [26]. Moreover, products and strategies are constantly tested, refined, and even co-created in close cooperation with customers or suppliers [137,138]. Digitalized Interactive Platform offerings, such as the Apple Watch NikePlus, allow for joint enactment of interactional value creation based on a digitized, networked arrangements of artifacts, persons, processes, and interfaces [98]. This enables them to create a blue ocean by carving out uncontested market spaces that are less—if at all—dominated by competition [139].

Reconstructionist business logic often embraces technology that allows a move away from traditional, often hierarchical, modes of decision making, in order to better reflect changing market needs by rendering real-time adaptation possible. By becoming more agile and adaptive, firms can maximize value for customers and reduce costs for themselves [26]. To fully exploit their transformative potential and to actually create value from data, organizations need to fundamentally alter their core business to make it more agile, lean, and cost-effective. Analytics provides real-time and predictive insights, but its actual transformative capacity lies in its deployment and usage of the innovation process [15]. The more holistic digital efforts are embraced in order to enhance value for customers and firm performance, the more completely a firm's core dynamic capabilities will be shaped and refined. This also affects a firm's USP or product offering; for example, going digital at the product level, i.e., by equipping conventional garments with sensors, creates a novel service and value proposition.

Some transformative models incorporate a product as a service and a pay-per-use approach by charging customers based on usage rather than requiring them to buy the products. This essentially means that instead of outcomes, not products, are sold, and a product-based business model becomes a service offering. This can benefit both parties, since costs for customers only incur so long as offerings create value, and companies can serve a broader base of customers without tying up more resources. However, it does have financial implications. For example, BMW DriveNow does not generate a large up-front financial revenue from a car sale, but a constant flow of smaller amounts over time. Consequently, customer retention becomes critical [21].

Shared-Value/Sustainable Elements: Closed Loop Processes—Asset Sharing-Collaborative Ecosystems

It is challenging to design business models in such a way that they capture economic value for the firm by delivering social and environmental benefits [11]. Empirical research on the effects of sustainable management on firm performance-which are supposed to simultaneously cut costs and protect the environment-suggests that firms need to build specific capabilities for process innovation and implementation in order to positively influence firm performance [140]. Motivations that induce corporate ecological responsiveness include competitiveness, legitimation, and ecological responsibility [139]; however, resource-based and institutional factors influence corporate sustainable development [140].

The concept of the circular economy (CE) [141] is discussed as a potential solution that creates synergies between environmental and economic development goals; however, it is rooted mainly in web articles and textbooks and has only been poorly integrated in scholarly study of management [72]. A strand of empirical research is emerging on firms $[142,143]$ or entire industries transitioning to 
circular business models as well as on the development of indicators of circularity [144]. (For a recent review and typology of circular business models, see Lüdeke-Freud [45].) Sustainable transformative business models incorporate circular economic logic and often (re)configure linear value chains and consumption patterns with closed loops that incorporate resource efficiency, recycling, and reuse of products already at the conceptualization stage $[40,145,146]$. Alternatively, sufficiency-driven business models seek to moderate overall resource use by avoiding built-in obsolescence, extending product life cycles, and providing eco-efficient technology solutions [59]. These minimize both resource use and costs.

Sustainable business models also succeed because they share value and cost assets. For example, Airbnb allows homeowners to share their home with tourists, thus providing hotel-like services without actually owning any hotels rooms, i.e., tangible assets. Similarly, Uber shares existing assets with car owners. Typically, online platforms and marketplaces that connect producers with customers unlock value for both partners. The sharing potential, or the "sharing economy" [147], is made possible by digital platforms that allow an easy match of supply and demand; the sharing economy is projected to increase in global revenues by more than $20 \%$, or up to $\$ 335$ billion, by 2025 [148]. At the same time, entry barriers into many traditional industries are rendered irrelevant, since new entrants no longer need to own the assets but instead to merely act as intermediaries [26]. Unlocking transformative potential may not only answer the issue of diminishing sector boundaries, but can actually potentiate this process.

Collaborative ecosystems are essential in a sustainable digital economy. By collaborating across the network of partners and institutions, companies can jointly create new capabilities and accelerate innovation [149]. Sustainable innovations and platforms are successful because they enable collaboration along the value chain and across sector borders by facilitating cooperation among supply-chain partners and better allocating risks, which may lead to cost reductions and more efficient resource use for all participating agents.

\subsubsection{Organizational Strategy, Culture, and Structure}

A firm's strategy proactively balances transforming the scope of one's business with building on one's core competences; this is essential for staying competitive in the digital age, since competition often comes laterally, from new players [150]. Today, some of the most valuable assets of a company - data and customer base-are not accounted for in the balance sheet, yet customers can create a powerful network effect and help when the company introduces complementary services. For example, Amazon can easily leverage its Prime customer base to introduce new services or products. A customer-centric strategy requires a firm to come up with new ways to meet changing customer needs. John Deere, a traditional tractor producer, followed this approach by hiring engineers to build new capabilities via value-added services, such as satellite navigation, artificial intelligence, and predictive maintenance to optimize crop output [150]. However, building new capabilities while exploiting existing ones "is like repairing an aircraft engine while flying" [150].

To embrace and build sustainable transformative capacity, firms need to alter their organizational mind and culture. Thus far, only anecdotal evidence exists on this phenomenon. An analytics-driven transformation must be based on a cultural change as much as on crunching data and numbers. Jeff Immelt [151], CEO of General Electric (GE), openly admitted that, while he first thought transformation was all about technology, he soon found out that he needed a much more holistic approach, including major behavioral, cultural, and structural changes. "We want to treat analytics like it's as core to the company over the next 20 years as material science has been over the past 50 years [...] in order to do that, we have to add technology, we have to add people, we have to change our business models. We have to be willing to do all those things." [151]. Consequently, GE decided to become a cloud-based platform, combining its own information flows with customer data, as well as an application company. This meant a drastic cultural makeover for GE, a "culture of simplification", with fewer hierarchical layers, fewer processes, fewer decision points, but continuous reviews and fluid planning. Similarly, 
Intel believed that it needed a more collaborative culture to help gain an edge in certain technologies, and it took small steps in that direction. After agreeing on an overall vision, they developed new ways to break down communication barriers and bring people together, including 220 video conferencing rooms, novel search functions to sharepoint implementation, and setting up teams around accounts rather than internal departments [19].

Essentially, embracing data analytics also means instilling a company-wide culture of data orientation, and building teams with complementary data skills [90]. The same applies for adopting a sustainable shared-value based strategy and organizational culture. Technology and infrastructure can only be created with a strong organizational foundation; insights are gained in loops and transformed into action, and adoption is delivered. In order to enact such an organizational culture, the organizational structure also must be realigned; however, the structural alignment seems to be one of the most significant challenges to organizations' effectiveness of incorporating sustainability, data, and analytics [152]. Knowledge management can help mediate the relationships among culture, structure, and strategy [153].

\subsubsection{Sustainable Transformative Value Chain}

Transformative sustainable business models are based on shared-value logic and on innovative digital solutions that can reduce costs, enhance resource efficiency, advance customer experience, and add value, both within single stages of the value chain and across its entirety. From connected cars in the automotive industry to smart virtual learning in the education sector, almost all industries are undergoing at least some sort of technology-driven transition in their value chains [154]. As a result, the traditional concept of the value chain, as established by Michael Porter in 1985 [155], needs to be carefully rethought. To maximize synergies based on digital technologies, the transformative value chain must be multilayered and involve future customers at the product/service design stage.

Technology has altered the entire consumer decision journey or purchasing path. Long before a purchase is made, consumers often systematically scan the web for relevant information, which provides an opportunity for firms to understand preferences and to influence buying behavior. Therefore, social media and online reviews open up new avenues for targeting and digital marketing, and enable co-creation and personalized product development [156]. Novel forms of customer/user engagement, including gamification elements and augmented reality, can enrich purchasing decisions and customer experience [157]. Similarly, 3-D printing may reinvent how product development is operated, by allowing customers to co-design products and print prototypes. At the same time, it revolutionizes the entire supply chain, including warehousing, inventory management, logistics, and distribution [158].

In addition, companies leverage expertise not only from customers but also from experts and lead users outside the company. Open-innovation and crowd-sourcing have been used in a wide range of business applications. For example, Procter \& Gamble reported that they moved from R\&D (research and development) to C\&D (connect and develop), with more than $35 \%$ of their innovations being based on open innovation [159]. Open innovation is often both quick and inexpensive; in a study of 489 projects of a large European manufacturer, open innovation turns out to be financially more attractive and quicker in delivery than traditional projects [160].

Digitized operations allow firms to quickly change any component, machine, or process without compromising on productivity, speed, or quality. This leads to unprecedented levels of flexibility in manufacturing. For example, Siemens increased its output by $8.5 \%$, based solely on digitized operational excellence [161]. With rising connectivity in the industrial Internet and falling costs for connecting, storing, and processing machine data, predictive maintenance and optimized operations have enhanced efficiency and contributed greatly to more sustainable resource use. For example, Predix, GE's cloud-based operating system for industrial applications, hosts many applications for asset-performance management to increase asset reliability and reduce maintenance costs and resource use [162]. At the same time, local small-scale manufacturing combines classic 
production techniques with cyber-physical production systems, which leads to the "Internet of things, data and services" [163]. Additive manufacturing (3-D printing) replaces traditional sourcing, direct procurement, and manufacturing. It allows the production of more complex products, enables customization and on-demand production, and helps reduce inventory. It also enhances sustainability by optimizing logistics and transportation, since companies may print products closer to the point of need, which in turn may reduce a company's $\mathrm{CO}_{2}$ footprint. Decentralized manufacturing may also bring offshore manufacturing from emerging economies back to developed ones. A literature review covering 191 papers published from 1994 to 2007 on sustainable supply chains shows that research is dominated by environmental rather than social issues in supply-chain management [164].

Demand-driven supply chains are based on a combination of data analytics and monitored real-time shifts in demand, and they reduce inventories and the risk of excess stock $[165,166]$. Enterprise resource planning (ERP) systems includes various applications, from customer relationship management (CRM) to sourcing, manufacturing, and forecasting, and they allow for real-time data on all entities of the supply chain. Electronic Kanban (eKanban) uses the Internet to instantly route messages to external suppliers to provide real-time visibility to the supply chain, making lower inventory levels, less transportation, and reduced bound capital possible. BMW was able to capitalize on major savings by using an eKanban system with their supplier Lear Corp. sharing their resource planning in real time. Synergies between societal progress and productivity in a multilayered digital value chain give rise to a more viable sustainable understanding of productivity and the fallacy of a focus on mere short-term economic gains [10].

Distribution in transformative value chains often uses multiple channels simultaneously. Effective omni-channel distribution in response to customers that move from bricks to clicks requires firms to think of different channels as complementing each other [150].

In short, primary activities in transformative sustainable value chains are no longer linear, but complex and often client/user focused. Supporting activities are based on a shared-value product and/or service conceptualization and collaborative closed-loop ecosystems. Figure 2 illustrates potential new configurations of the value chain.

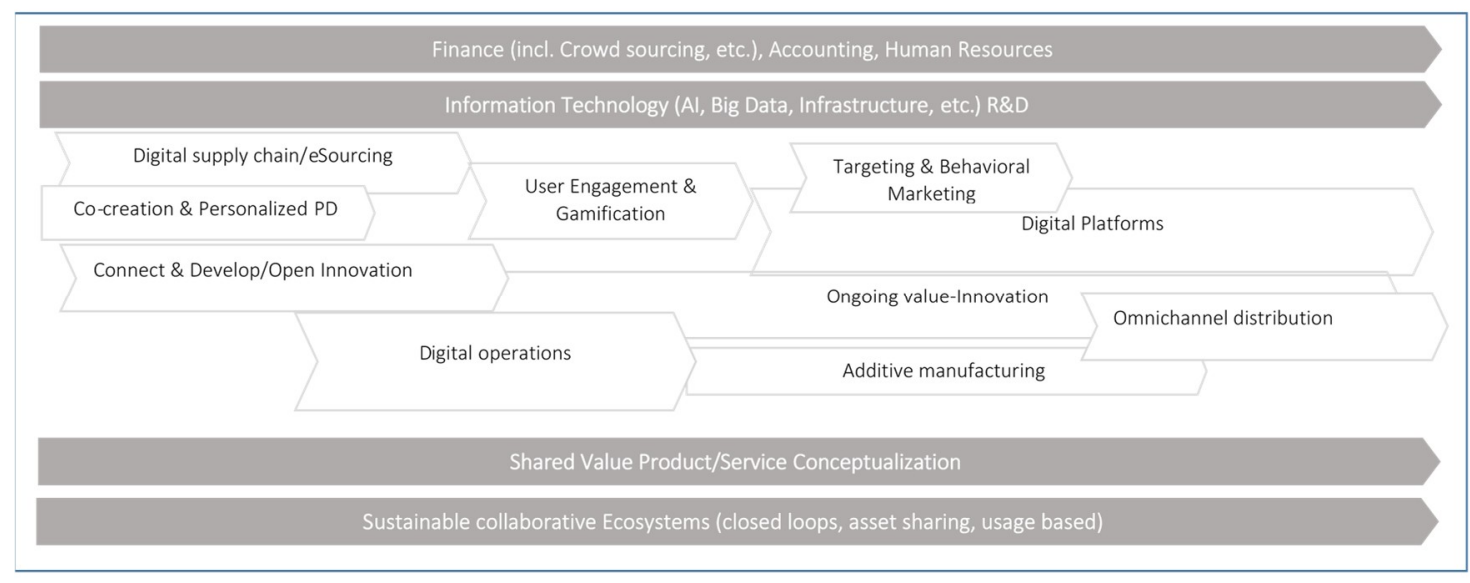

Figure 2. Transformative sustainable value chain.

\subsection{Individual Layer}

Transformative Leadership \& Digital Mindset

Implementing transformative action that is based on analytics and sustainability requires leadership from the top if it is to reach the core of the business model [90]. Changes on the magnitude of the digital imperative and shared-value logic transform how companies organize, operate, manage talent, and essentially create value. Doz and Kosonen [167] proposed a repertoire of concrete leadership 
actions that enable the meta-capabilities needed to accelerate the renewal and transformation of business models.

While CEOs are constantly under pressure to perform, they may choose to underestimate the impact of the radical shift and fail to take on an active transition. A recent survey by McKinsey [90] shows that three-quarters of leaders that committed themselves to big-data analytics brought in less than $1 \%$ in revenue or cost improvements. While such individual gains may seem negligible in the short term, the aggregate of such measures can have a lasting impact. Only a small minority of CEOs walk the talk with regards to digitization. However, CEOs need to make sure that: first, the right kind of conversations are occurring in the boardroom; second, the right people are empowered to act; and third, direct intervention will enable transition from experience-based decision making to data-based decision making [90], as well as from pure economic value to shared-value logic. In fact, leaders need to ensure that sustainable principles, data flows, and analytics are embedded in dynamic capabilities and are centered at the core of every organizational process.

A striking example of how a 125-year old classic conglomerate firm reinvented itself in the past 16 years to become a digital industrial company is General Electrics. Jeffrey Immelt [168], the CEO who led this massive makeover, points to several crucial transformative leadership lessons. First, transformative leaders need to be focused on a clear point of view and must coordinate all initiatives towards that vision. They also need to be disciplined and stay away from ideas that do not fit. Second, the leader needs to rewire his/her brain in order to be utterly convinced that the survival of the company depends on the change. Third, this sense of existential urgency for change needs to be understood by all people in the organization. Fourth, the leader must make a bold, irreversible, and sustained commitment to the transformation. Fifth, (s)he needs to be resilient, anticipate tough times, and persevere. Sixth, the leader needs to proactively listen, act, and stay open to the organization, pivoting on newly-acquired knowledge while at the same time continuing to push forward. Finally, (s)he needs to embrace new talent, a new culture, and new ways of doing things. In fact, many of these recommendations echo the work of Kotter's change principles $[169,170]$.

To turn modeling outputs into tangible business actions, organizations need "translators" that connect the needs of the company units with the technical skills of the modelers. Senior leader involvement and organizational structure play a critical role in a firm's adoption of effective analytics $[152,171]$. In a survey by MIT Sloan Management Review and Capgemini Consulting in 2013 , only $38 \%$ of respondents stated that digital transformation was a permanent fixture on their CEO's agenda. However, when CEOs shared their vision for digital transformation, $93 \%$ of employees felt that it was the right thing for the organization; unfortunately, only $36 \%$ of CEOs shared their vision [19].

\section{Discussion and Conclusions}

The rapid pace of digitization, coupled with the need for more sustainability in business, gives rise to substantial opportunities for creating new value propositions. We built on business model theory, because the business model can be conceived as "a focusing device that mediates between technology development and economic value creation" [66] (p. 532). We attempted to contribute to developing theory by discussing the theoretical foundations of business model innovation, shared-value logic, and digital technologies. Information technology and data science allow organizations to constantly evolve or disrupt their value propositions, which raises fundamental questions about the underlying capabilities, processes, and structures by which firms innovate and adapt $[15,16]$. The focus was on dynamic transformative capabilities that enable novel value propositions, based on both reconstructionist and sustainable logic. Our analysis and our theoretical development attempted to bridge the bodies of literature on business models and digitization. We drew on a wide body of literature in business model innovation, sustainable business models, and digitization to conceptualize a multifaceted framework of transformative and sustainable business models that involve three layers: the external environment (technological, economic, social, and environmental), 
the organization, and the individual. Our holistic, systems-level perspective entails these layers to be both horizontally and vertically coherent. Key elements of transformative business models adhere to both innovative reconstructionist and sustainable shared-value logics; these include co-creation, usage-based pricing, agility and adaptability, closed-loop/circular processes, asset-sharing, and participating in a collaborative business ecosystem. We also sketched potential configurations of the value chain that allow for synchronous, often non-linear interactions of functions, skills, and processes.

A consensus is growing in the literature that firms need to change, adapt, and innovate their business models to appropriate value from technological innovation $[79,172,173]$ and sustain success over time $[25,53,67]$. Digitalization and the destabilizing effect of VUCA environments make constant innovation a necessity, causing the whole business model to become a source of innovation itself [174]. Business models allow for a "discovery-driven" [68] experiential approach, rather than an analytical approach. We suggest that firms sorely need to develop and assign dynamic transformative capabilities and to creatively (re)combine elements of a multilayered value chain in order to deliver novel sustainable solutions that capitalize on digital technologies that customers value. Consequently, our conceptualization puts an ongoing transformation capacity based on dynamic capabilities at the core of the business model, to sustain competitive advantage in turbulent digital environments. Similarly, recent empirical findings, such as from Hacklin [175], show that firms that proactively substitute key elements of their primary business experience a better fit with new value landscapes caused by industry-level value migration. We suggest that transformative capacity is the basis of constant business model innovation, which yields both higher returns than product or process innovations as well as sustainable value-creation opportunities in dynamic environments. Sustained value creation in digital environments can no longer be realized through value-chain configurations, strategic networks formation, or exploitation of core competencies; instead, value is created through innovation based on reconstructionist and shared-value or circular-economy logics that are often enabled by digital technology. We suggest that research on business model innovation will benefit from an approach that integrates sustainable business models and digital technology perspectives.

The digital imperative (or the inability of a majority of firms to adopt new digital realities) shows that organizations must be able to sense opportunities, craft transformative sustainable business models to capitalize on them, and relentlessly reconfigure their organizational structures and strategies-and sometimes even their industries-as external dynamics and technologies shift. Firms must not only understand their current business models and identify existing and potential future drivers of digital value, but also use their dynamic capabilities to strategically exploit digitization. Transformative capacity requires the organization and its top management to develop and validate conjectures, and to realign assets and competences on an ongoing basis. The SVIDT-method (Strengths, Vulnerability, and Intervention assessment related to Digital Threats) [22] can be used to assess and manage the vulnerabilities of human systems with respect to digital threats and changes. To encompass digital realities and a shared-value logic, the theory of a firm needs to be enlarged to adequately allow for opportunity, coordination beyond established firm boundaries, variation of capability levels across firms, complementarities, co-creation, and specialization. Only dynamic capabilities, culture, and mindsets allow a corporation to orchestrate its resources, competences, and other assets in a timely and resilient fashion, or to completely revamp what the firm is doing to maintain a good fit with (or sometimes transform) the business ecosystem, markets, and/or industries the enterprise occupies. Transformative sustainable business models are essential to assessing when and how to ally with other market players or potential competitors, in order to fully exploit or leverage network effects or other synergies. At the same time, the efficacy of (dynamic) organizational capabilities varies with (digital) market dynamism, making them interdependent with the external environment.

The limitations of this paper relate to the need to empirically test the issues we have pointed out in relation to the external dynamics and to business model innovation. Both qualitative and quantitative research is needed to build further propositions and hypotheses that would validate our framework. 
This paper is a first step in attempting to understand how innovation is linked to sustainable value creation through business models and to dynamic capabilities that are necessary to enable sustainable value propositions based on digital technologies.

This paper identifies a number of pathways for future research on sustainable business model innovation and digitization. These call for transdisciplinary processes that include interdisciplinary applied research and a multi-stakeholder discourse to adequately integrate epistemics from science and practice $[176,177]$. Transdisciplinarity processes afford sustainability learning [176] which is essential for complex situations caused by digitization that involve many uncertainties. Such research is not only assessed by its disciplinary standards but also by its potential societal impact since the research is simultaneously applied in a real-world setting [178].

For instance, an integrated view of the largely-separate literatures on business models and technology - notably on technological advances rendered possible through digitization-may generate novel insights into sustained value innovation. How can digital technologies foster sustained value innovation? How will disruptive, sustainable innovations based on digital technology impact industry structures? What are the implications of moving the locus of value creation outside the firm?

Similarly, the link between digitization and the circular economy warrants a systematic scholarly inquiry. How can firms shape new value propositions based on closed-loop processes? Which organizational capabilities based on digital technologies are necessary for circular business models? Another promising research avenue involves marrying circular economy concepts with organizational theory [72]. A strand of empirical research is emerging on firms [142] and entire industries transitioning to circular business models, as well as on the development of indicators of circularity [144]. Moreover, the resource-sharing aspect of sustainable business models-also conceptualized as the sharing economy [147]—deserves scholarly attention, particularly in light of the digital economy, where digital platforms allow an easy match of supply and demand. How will potential sharing, rendered possible by digital platforms, challenge existing business model conceptualizations and enable new sustainable business models?

Alternatively, the perspective of organizational theory, such as contingency theory, may help to shed light on how to create a better fit among sustainability, digital technology, and business models. How can organizations integrate, analyze, and exploit data to generate sustainable value-propositions for customers who share data across industries?

Funding: This research received no external funding.

Acknowledgments: The author thanks Roland Scholz, Gerald Steiner, and three anonymous reviewers for their insightful and constructive feedback on a previous version of this paper.

Conflicts of Interest: The author declares no conflict of interest.

\section{References}

1. Burns, T.; Stalker, G.M. The Management of Innovation; Tavistock Publications: London, UK, 1961.

2. Galbraith, J.R. Designing Complex Organizations; Addison Wesley: Reading, MA, USA, 1973.

3. Teece, D.J.; Pisano, G.; Shuen, A. Dynamic capabilities and strategic management. Strat. Manag. J. 1997, 18, 509-533. [CrossRef]

4. Scholz, R.W. Sustainable digital environments: What major challenges is humankind facing? Sustainability 2016, 8, 726. [CrossRef]

5. Porter, M.E. Strategy and the internet. Harv. Bus. Rev. 2001, 79, 62-78. [PubMed]

6. Porter, M.E.; Millar, V.E. How information gives you competitive advantage. Harv. Bus. Rev. 1985, 4, 149-160.

7. Porter, M.E.; Heppelmann, J.E. How smart, connected products are transforming competition. Harv. Bus. Rev. 2014, 92, 64-88.

8. Bansal, P.; Roth, K. Why companies go green: A model of ecological responsiveness. Acad. Manag. J. 2000, 43, 717-736.

9. Bansal, P. Evolving sustainably: A longitudinal study of corporate sustainable development. Strat. Manag. J. 2005, 26, 197-218. [CrossRef] 
10. Porter, M.E.; Kramer, M.R. Creating shared value-How to reinvent capitalism and unleash a wave of innovation and growth. Harv. Bus. Rev. 2011, 89, 62-77.

11. Schaltegger, S.; Lüdeke-Freund, F.; Hansen, E.G. Business cases for sustainability: The role of business model innovation for corporate sustainability. Int. J. Innov. Sustain. Dev. 2012, 6, 95-119. [CrossRef]

12. Malecki, E.J.; Moriset, B. The Digital Economy: Business Organization, Production Processes and Regional Developments; Routledge: Abingdon-on-Thames, UK, 2007.

13. Manyika, J.; Chui, M.; Brown, B.; Bughin, J.; Dobbs, R.; Roxburgh, C.; Hung Byers, A. Big data: The next frontier for innovation, competition, and productivity. In McKinsey Global Institute Report; McKinsey Global Institute: San Francisco, CA, USA, 2011; pp. 1-156.

14. George, G.; Osinga, E.C.; Lavie, D.; Scott, B.A. Big Data and Data Science Methods for Management Research; Academy of Management Briarcliff Manor: New York, NY, USA, 2016.

15. George, G.; Lin, Y. Analytics, innovation, and organizational adaptation. Innovation 2017, 19, $16-22$. [CrossRef]

16. George, G.; Haas, M.R.; Pentland, A. Big data and management. Acad. Manag. J. 2014, 57, 321-326. [CrossRef]

17. Sivarajah, U.; Kamal, M.M.; Irani, Z.; Weerakkody, V. Critical analysis of big data challenges and analytical methods. J. Bus. Res. 2017, 70, 263-286. [CrossRef]

18. Constantiou, I.D.; Kallinikos, J. New games, new rules: Big data and the changing context of strategy. J. Inf. Technol. 2015, 30, 44-57. [CrossRef]

19. Fitzgerald, M.; Kruschwitz, N.; Bonnet, D.; Welch, M. Embracing digital technology: A new strategic imperative. MIT Sloan Manag. Rev. 2013, 55, 1-12.

20. McAfee, A.; Brynjolfsson, E. Big data: The management revolution. Harv. Bus. Rev. 2012, 90, 60-68. [PubMed]

21. Agarwal, V.; Arora, V.; Renker, K. Evolving Service Centric Business Models: Quest for Profitability and Predictability; Accenture Report; Accenture: Dublin, Ireland, 2013.

22. Scholz, R.W. Digital threat and vulnerability management: The svidt method. Sustainability 2017, 9, 554. [CrossRef]

23. Iansiti, M.; Lakhani, K.R. Managing our hub economy-Strategy, ethics, and networks in the age of the digital superpowers. Harv. Bus. Rev. 2017, 95, 85-92.

24. Venkatraman, N.; Prescott, J.E. Environment-strategy coalignment: An empirical test of its performance implications. Strat. Manag. J. 1990, 11, 1-23. [CrossRef]

25. Teece, D.J. Technological innovation and the theory of the firm: The role of enterprise-level knowledge, complementarities, and (dynamic) capabilities. Handb. Econ. Innov. 2010, 1, 679-730.

26. Kavadias, S.; Ladas, K.; Loch, C. The transformative business model. Harv. Bus. Rev. 2016, 94, 91-98.

27. Joyce, A.; Paquin, R.L. The triple layered business model canvas: A tool to design more sustainable business models. J. Clean. Prod. 2016, 135, 1474-1486. [CrossRef]

28. Schaltegger, S.; Hansen, E.G.; Lüdeke-Freund, F. Business models for sustainability: Origins, present research, and future avenues. Organ. Environ. 2016, 29, 3-10. [CrossRef]

29. Dyllick, T.; Hockerts, K. Beyond the business case for corporate sustainability. Bus. Strategy Environ. 2002, 11, 130-141. [CrossRef]

30. Boons, F.; Lüdeke-Freund, F. Business models for sustainable innovation: State-of-the-art and steps towards a research agenda. J. Clean. Prod. 2013, 45, 9-19. [CrossRef]

31. Barrett, M.; Davidson, E.; Prabhu, J.; Vargo, S.L. Service innovation in the digital age: Key contributions and future directions. MIS Q. 2015, 39, 135-154. [CrossRef]

32. Chesbrough, H.W. Open Innovation: The New Imperative for Creating and Profiting from Technology; Harvard Business Press: Brighton, MA, USA, 2006.

33. Seelos, C.; Mair, J. Profitable business models and market creation in the context of deep poverty: A strategic view. Acad. Manag. Perspect. 2007, 21, 49-63. [CrossRef]

34. Teece, D.J. Business models, business strategy and innovation. Long Range Plan. 2010, 43, 172-194. [CrossRef]

35. Dodgson, M.; Gann, D.M.; Phillips, N. The Oxford Handbook of Innovation Management; OUP Oxford: Oxford, UK, 2013.

36. Zott, C.; Amit, R. Business model design: An activity system perspective. Long Range Plan. 2010, 43, $216-226$. [CrossRef]

37. Osterwalder, A.; Pigneur, Y. Business Model Generation: A Handbook for Visionaries, Game Changers, and Challengers; John Wiley \& Sons: Hoboken, NJ, USA, 2010. 
38. Osterwalder, A.; Pigneur, Y.; Tucci, C.L. Clarifying business models: Origins, present, and future of the concept. Available online: https: / / aisel.aisnet.org/cgi/viewcontent.cgi?article=3016\&context=cais (accessed on 26 November 2018).

39. Schaltegger, S. Sustainability as a driver for corporate economic success. Soc. Econ. 2011, 33, 15-28. [CrossRef]

40. De Sousa Jabbour, A.B.L.; Jabbour, C.J.C.; Godinho Filho, M.; Roubaud, D. Industry 4.0 and the circular economy: A proposed research agenda and original roadmap for sustainable operations. Ann. Oper. Res. 2018. [CrossRef]

41. Wirtz, B.W.; Pistoia, A.; Ullrich, S.; Göttel, V. Business models: Origin, development and future research perspectives. Long Range Plan. 2016, 49, 36-54. [CrossRef]

42. Bocken, N.M.P.; Short, S.W.; Rana, P.; Evans, S. A literature and practice review to develop sustainable business model archetypes. J. Clean. Prod. 2014, 65, 42-56. [CrossRef]

43. Evans, S.; Vladimirova, D.; Holgado, M.; Van Fossen, K.; Yang, M.; Silva, E.A.; Barlow, C.Y. Business model innovation for sustainability: Towards a unified perspective for creation of sustainable business models. Bus. Strategy Environ. 2017, 26, 597-608. [CrossRef]

44. Geissdoerfer, M.; Vladimirova, D.; Evans, S. Sustainable business model innovation: A review. J. Clean. Prod. 2018. [CrossRef]

45. Luedeke-Freud, F.; Gold, S.; Bocken, N.M.P. A review and typology of circular economy business model patterns. J. Ind. Ecol. 2018. [CrossRef]

46. Yang, M.; Evans, S.; Vladimirova, D.; Rana, P. Value uncaptured perspective for sustainable business model innovation. J. Clean. Prod. 2017, 140, 1794-1804. [CrossRef]

47. Teece, D.J. Profiting from innovation in the digital economy: Enabling technologies, standards, and licensing models in the wireless world. Res. Policy 2018. [CrossRef]

48. Nambisan, S.; Lyytinen, K.; Majchrzak, A.; Song, M. Digital innovation management: Reinventing innovation management research in a digital world. MIS Q. 2017, 41, 223-238. [CrossRef]

49. Amit, R.; Zott, C. Value creation in e-business. Strat. Manag. J. 2001, 22, 493-520. [CrossRef]

50. Teece, D.; Linden, G. Business models, value capture, and the digital enterprise. J. Organ. Des. 2017, 6, 1-14. [CrossRef]

51. Benner, M.J.; Tushman, M.L. Reflections on the 2013 decade award-“Exploitation, exploration, and process management: The productivity dilemma revisited" ten years later. Acad. Manag. Rev. 2015, 40, 497-514. [CrossRef]

52. Achtenhagen, L.; Melin, L.; Naldi, L. Dynamics of business models—Strategizing, critical capabilities and activities for sustained value creation. Long Range Plan. 2013, 46, 427-442. [CrossRef]

53. Chesbrough, H. Business model innovation: Opportunities and barriers. Long Range Plan. 2010, 43, $354-363$. [CrossRef]

54. Tranfield, D.; Denyer, D.; Smart, P. Towards a methodology for developing evidence-informed management knowledge by means of systematic review. Br. J. Manag. 2003, 14, 207-222. [CrossRef]

55. Moher, D.; Liberati, A.; Tetzlaff, J.; Altman, D.G. Preferred reporting items for systematic reviews and meta-analyses: The prisma statement. Ann. Intern. Med. 2009, 151, 264-269. [CrossRef] [PubMed]

56. Mayring, P. Qualitative Inhaltsanalyse-Grundlagen und Techniken; Beltz: Weinheim, Germany; Basel, Switzerland, 2003.

57. George, G.; Bock, A.J. The business model in practice and its implications for entrepreneurship research. Entrep. Theory Pract. 2011, 35, 83-111. [CrossRef]

58. Yip, A.W.H.; Bocken, N.M.P. Sustainable business model archetypes for the banking industry. J. Clean. Prod. 2018, 174, 150-169. [CrossRef]

59. Bocken, N.; Short, S. Towards a sufficiency-driven business model: Experiences and opportunities. Environ. Innov. Soc. Trans. 2016, 18, 41-61. [CrossRef]

60. Jabłoński, M. Value migration to the sustainable business models of digital economy companies on the capital market. Sustainability 2018, 10, 3113. [CrossRef]

61. Li, W.Z.; Liu, K.C.; Belitski, M.; Ghobadian, A.; O’Regan, N. E-leadership through strategic alignment: An empirical study of small- and medium-sized enterprises in the digital age. J. Inf. Technol. 2016, 31, 185-206. [CrossRef]

62. Piscicelli, L.; Ludden, G.D.; Cooper, T. What makes a sustainable business model successful? An empirical comparison of two peer-to-peer goods-sharing platforms. J. Clean. Prod. 2018, 172, 4580-4591. [CrossRef] 
63. Bleicher, J.; Stanley, H. Digitization as a catalyst for business model innovation a three-step approach to facilitating economic success. J. Bus. Manag. 2016, 62-71.

64. Bellman, R.; Clark, C.E.; Malcolm, D.G.; Craft, C.J.; Ricciardi, F.M. On the construction of a multi-stage, multi-person business game. Oper. Res. 1957, 5, 469-503. [CrossRef]

65. Chesbrough, H. Open Business Models: How to Thrive in the New Innovation Landscape; Harvard Business Press: Brighton, MA, USA, 2006.

66. Chesbrough, H.; Rosenbloom, R.S. The role of the business model in capturing value from innovation: Evidence from xerox corporation's technology spin-off companies. Ind. Corp. Chang. 2002, 11, 529-555. [CrossRef]

67. Massa, L.; Tucci, C.L. Business model innovation. Oxf. Handb. Innov. Manag. 2013, 20, 18.

68. McGrath, R.G. Business models: A discovery driven approach. Long Range Plan. 2010, 43, 247-261. [CrossRef]

69. Zott, C.; Amit, R.; Massa, L. The business model: Recent developments and future research. J. Manag. 2011, 37, 1019-1042.

70. Foss, N.J.; Saebi, T. Fifteen years of research on business model innovation: How far have we come, and where should we go? J. Manag. 2017, 43, 200-227. [CrossRef]

71. Klewitz, J.; Hansen, E.G. Sustainability-oriented innovation of SMES: A systematic review. J. Clean. Prod. 2014, 65, 57-75. [CrossRef]

72. Lahti, T.; Wincent, J.; Parida, V. A definition and theoretical review of the circular economy, value creation, and sustainable business models: Where are we now and where should research move in the future? Sustainability 2018, 10, 2799. [CrossRef]

73. Masi, D.; Day, S.; Godsell, J. Supply chain configurations in the circular economy: A systematic literature review. Sustainability 2017, 9, 1602. [CrossRef]

74. Hall, J.K.; Daneke, G.A.; Lenox, M.J. Sustainable development and entrepreneurship: Past contributions and future directions. J. Bus. Ventur. 2010, 25, 439-448. [CrossRef]

75. Elliot, S. Transdisciplinary perspectives on environmental sustainability: A resource base and framework for it-enabled business transformation. MIS Q. 2011, 35, 197-236. [CrossRef]

76. Baden-Fuller, C.; Morgan, M.S. Business models as models. Long Range Plan. 2010, 43, 156-171. [CrossRef]

77. Doganova, L.; Eyquem-Renault, M. What do business models do? Innovation devices in technology entrepreneurship. Res. Policy 2009, 38, 1559-1570. [CrossRef]

78. Massa, L.; Tucci, C.L.; Afuah, A. A critical assessment of business model research. Acad. Manag. Ann. 2017, 11, 73-104. [CrossRef]

79. Baden-Fuller, C.; Haefliger, S. Business models and technological innovation. Long Range Plan. 2013, 46, 419-426. [CrossRef]

80. Evanschitzky, H.; Eisend, M.; Calantone, R.J.; Jiang, Y. Success factors of product innovation: An updated meta-analysis. J. Prod. Innov. Manag. 2012, 29, 21-37. [CrossRef]

81. Dougherty, D.; Dunne, D.D. Digital science and knowledge boundaries in complex innovation. Organ. Sci. 2012, 23, 1467-1484. [CrossRef]

82. Arnold, C.; Kiel, D.; Voigt, K. How the industrial internet of things changes business models in different manufacturing industries. Int. J. Innov. Manag. 2016, 20, 1-14. [CrossRef]

83. OECD. Oecd Digital Economy Outlook 2017; OECD: Paris, France, 2017.

84. Lu, Y. Industry 4.0: A survey on technologies, applications and open research issues. J. Ind. Inf. Integr. 2017, 6, 1-10. [CrossRef]

85. Roblek, V.; Meško, M.; Krapež, A. A Complex View of Industry 4.0; SAGE Open: Newbury Park, CA, USA, 2016.

86. Parker, G.; Van Alstyne, M.; Jiang, X. Platform ecosystems: How developers invert the firm. Manag. Inf. Syst. Q. 2017, 41, 255-266. [CrossRef]

87. Manyika, J.; Chui, M.; Bughin, J.; Dobbs, R.; Bisson, P.; Marrs, A. Disruptive Technologies: Advances that Will Transform Life, Business, and the Global Economy; McKinsey Global Institute: San Francisco, CA, USA, 2013; Volume 180.

88. Andreessen, M. Why Software Is Eating the World. Available online: https://a16z.com/2016/08/20/whysoftware-is-eating-the-world/ (accessed on 26 November 2018).

89. Raposo, D.; Rodrigues, A.; Sinche, S.; Sá Silva, J.; Boavida, F. Industrial IOT monitoring: Technologies and architecture proposal. Sensors 2018, 18, 3568. [CrossRef] [PubMed] 
90. Henke, N.; Libarikian, A.; Wiseman, B. Straight Talk About Big Data. Available online: https://www. mckinsey.com/business-functions/digital-mckinsey/our-insights/straight-talk-about-big-data (accessed on 26 November 2018).

91. Porter, M.E.; Heppelman, J.E. Why every organization needs an augmented reality strategy. Harv. Bus. Rev. 2017, 95, 46-57.

92. Barton, D. Making advanced analytics work for you. Harv. Bus. Rev. 2012, 90, 78-83, 128. [PubMed]

93. Bone, J.; Emele, C.D.; Abdul, A.; Coghill, G.; Pang, W. The social sciences and the web: From 'lurking' to interdisciplinary 'big data' research. Methodol. Innov. 2016, 9, 2059799116630665. [CrossRef]

94. Halford, S.; Pope, C.; Weal, M. Digital futures? Sociological challenges and opportunities in the emergent semantic web. Sociology 2013, 47, 173-189. [CrossRef]

95. Arthur, W.B. Where Is Technology Taking the Economy? Available online: https://www.mckinsey.com/ business-functions / mckinsey-analytics / our-insights / where-is-technology-taking-the-economy (accessed on 26 November 2018).

96. Spielkamp, M. Inspecting algorithms for bias. MIT Technol. Rev. 2017, 120, 96-98.

97. Van Alstyne, M.W.; Parker, G.G.; Choudary, S.P. Pipelines, platforms, and the new rules of strategy. Harv. Bus. Rev. 2016, 94, 54-62.

98. Ramaswamy, V.; Ozcan, K. Offerings as digitalized interactive platforms: A conceptual framework and implications. J. Mark. 2018, 82, 19-31. [CrossRef]

99. Evans, D.S.; Schmalensee, R. Matchmakers: The New Economics of Multisided Platforms; Harvard Business Review Press: Boston, MA, USA, 2016.

100. Schaller, R.R. Moore's law: Past, present and future. IEEE Spectr. 1997, 34, 52-59. [CrossRef]

101. Metcalfe, B. Metcalfe's law after 40 years of ethernet. Computer 2013, 46, 26-31. [CrossRef]

102. Helfat, C.E.; Raubitschek, R.S. Product sequencing: Co-evolution of knowledge, capabilities and products. Strat. Manag. J. 2000, 21, 961-979. [CrossRef]

103. Helfat, C.E.; Raubitschek, R.S. Dynamic and integrative capabilities for profiting from innovation in digital platform-based ecosystems. Res. Policy 2018, 47, 1391-1399. [CrossRef]

104. Fernando, N.; Loke, S.W.; Rahayu, W. Mobile cloud computing: A survey. Future Gener. Comput. Syst. 2013, 29, 84-106. [CrossRef]

105. Armbrust, M.; Fox, A.; Griffith, R.; Joseph, A.D.; Katz, R.H.; Konwinski, A.; Lee, G.; Patterson, D.A.; Rabkin, A.; Stoica, I. Above the Clouds: A Berkeley View of Cloud Computing; Technical Report UCB/EECS-2009-28; EECS Department, University of California: Berkeley, CA, USA, 2009.

106. Ford, S.; Despeisse, M. Additive manufacturing and sustainability: An exploratory study of the advantages and challenges. J. Clean. Prod. 2016, 137, 1573-1587. [CrossRef]

107. Huang, S.H.; Liu, P.; Mokasdar, A.; Hou, L. Additive manufacturing and its societal impact: A literature review. Int. J. Adv. Manuf. Technol. 2013, 67, 1191-1203. [CrossRef]

108. Atluri, V.; Dietz, M.; Henke, N. Competing in a world of sectors without borders. Available online: https:/ / www.mckinsey.com/business-functions/mckinsey-analytics/our-insights/competing-ina-world-of-sectors-without-borders (accessed on 26 November 2018).

109. Woetzel, J.; Seong, J.; Wei Wang, K.; Manyika, J.; Chui, M.; Wong, W. China's Digital Economy: A Leading Global Force; McKinsey Global Institute: San Francisco, CA, USA, 2017; pp. 1-24.

110. Diaz, P.F. Chrris: A Framework for Continual, Holistic, Radical, Recombinative Innovation Using a Digital Sandbox; D.B.A. Capella University: Ann Arbor, MI, USA, 2017.

111. Shao, Y.; Shi, L. Cross-border open innovation of early stage tech incubation: A case study of forge, the first UK-China accelerator program. J. Open Innov. Technol. Mark. Complex. 2018, 4, 37. [CrossRef]

112. Gompers, P.; Lerner, J. The venture capital revolution. J. Econ. Perspect. 2001, 15, 145-168. [CrossRef]

113. UN. World Investment Report-Investment and the Digital Economy; United Nations: Geneva, Switzerland, 2017.

114. North, D.C. Institutions, Institutional Change and Economic Performance; Cambridge University Press: Cambridge, UK, 1990.

115. Scott, W.R. Institutions and Organizations; Sage Publications: Thousand Oaks, CA, USA, 1995.

116. Fagerberg, J.; Lundvall, B.-Å.; Srholec, M. Global Value Chains, National Innovation Systems and Economic Development; Lund University, CIRCLE-Center for Innovation, Research and Competences in the Learning Economy: Lund, Sweden, 2017. 
117. Lundvall, B.-Å. User-producer relationships, national systems of innovation and internationalisation. In National Systems of Innovation: Towards a Theory of Innovation and Interactive Learning; Frances Pinter Publishers Ltd.: London, UK, 1992; pp. 45-67.

118. Afuah, A. Redefining firm boundaries in the face of the internet: Are firms really shrinking? Acad. Manag. Rev. 2003, 28, 34-53. [CrossRef]

119. Coase, R.H. The nature of the firm. Economica 1937, 4, 386-405. [CrossRef]

120. Haier One Person Alone. Available online: http://www.haier.net/en/about_haier/one_person_alone/ (accessed on 3 August 2017).

121. Blank, S. Why the lean start-up changes everything. Harv. Bus. Rev. 2013, 91, 63-72.

122. Porter, M.E.; Kramer, M.R. Strategy and society: The link between competitive advantage and corporate social responsibility. Harv. Bus. Rev. 2006, 84, 78-92. [PubMed]

123. Stubbs, W.; Cocklin, C. Conceptualizing a "sustainability business model". Organ. Environ. 2008, 21, $103-127$. [CrossRef]

124. Horbach, J. Determinants of environmental innovation-New evidence from german panel data sources. Res. Policy 2008, 37, 163-173. [CrossRef]

125. MIT. 50 Smartest Companies 2017. In MIT Technology Review the Business Issue; MIT: Cambridge, MA, USA, 27 July 2017.

126. Cohen, W.M.; Levinthal, D.A. Absorptive capacity: A new perspective on learning and innovation. Adm. Sci. Q. 1990, 35, 128-152. [CrossRef]

127. Penrose, E. The Theory of the Growth of Firm; Oxford University Press: Oxford, UK, 1959.

128. Rubin, P.H. The expansion of firms. J. Political Econ. 1973, 81, 936-949. [CrossRef]

129. Wernerfelt, B. A resource-based view of the firm. Strat. Manag. J. 1984, 5, 171-180. [CrossRef]

130. Barney, J. Firm resources and sustained competitive advantage. J. Manag. 1991, 17, 99-120. [CrossRef]

131. Teece, D.J. Dynamic Capabilities and Strategic Management: Organizing for Innovation and Growth; Oxford University Press on Demand: Oxford, UK, 2009.

132. Helfat, C.E.; Peteraf, M.A. The dynamic resource-based view: Capability lifecycles. Strat. Manag. J. 2003, 24, 997-1010. [CrossRef]

133. Teece, D. Managers, markets and dynamic capabilities. In Dynamic Capabilities: Understanding Strategic Change in Organizations; Helfat, C., Finkelstein, S., Mitchell, W., Peteraf, M., Singh, D.J., Teece, D.J., Winter, S., Eds.; Blackwell: Oxford, UK, 2007; pp. 19-29.

134. March, J.G. Exploration and exploitation in organizational learning. Organ. Sci. 1991, 2, 71-87. [CrossRef]

135. O'Reilly, C.A.; Tushman, M.L. The ambidextrous organization. Harv. Bus. Rev. 2004, 82, 74-81, 140. [PubMed]

136. Kim, W.C.; Mauborgne, R.A. Blue Ocean Strategy, Expanded Edition: How to Create Uncontested Market Space and Make the Competition Irrelevant; Harvard Business Review Press: Boston, MA, USA, 2014.

137. Breidbach, C.F.; Maglio, P.P. Technology-enabled value co-creation: An empirical analysis of actors, resources, and practices. Ind. Mark. Manag. 2016, 56, 73-85. [CrossRef]

138. Prahalad, C.K.; Ramaswamy, V. The Future of Competition: Co-Creating Unique Value with Customers; Harvard Business Press: Brighton, MA, USA, 2004.

139. Kim, W.C.; Mauborgne, R.A. Blue Ocean Shift beyond Competing-Proven Steps to Inspire Confidence and Growth; MacMillan: London, UK, 2017.

140. Christmann, P. Effects of "best practices" of environmental management on cost advantage: The role of complementary assets. Acad. Manag. J. 2000, 43, 663-680.

141. MacArthur, E. Towards a Circular Economy-Economic and Business Rationale for an Accelerated Transition; Ellen MacArthur Foundation: Cowes, UK, 2013.

142. Núñez-Cacho, P.; Molina-Moreno, V.; Corpas-Iglesias, F.A.; Cortés-García, F.J. Family businesses transitioning to a circular economy model: The case of "mercadona". Sustainability 2018, 10, 538. [CrossRef]

143. Ceptureanu, S.-I.; Ceptureanu, E.-G.; Murswieck, R.G.D. Perceptions of circular business models in SMES. Amfiteatru Econ. 2018, 20, 310-324.

144. Molina-Sánchez, E.; Leyva-Díaz, J.; Cortés-García, F.; Molina-Moreno, V. Proposal of sustainability indicators for the waste management from the paper industry within the circular economy model. Water 2018, 10, 1014. [CrossRef]

145. Wells, P.; Seitz, M. Business models and closed-loop supply chains: A typology. Supply Chain Manag. 2005, 10, 249-251. [CrossRef] 
146. Nußholz, J.L.K. A circular business model mapping tool for creating value from prolonged product lifetime and closed material loops. J. Clean. Prod. 2018, 197, 185-194. [CrossRef]

147. Ranjbari, M.; Morales-Alonso, G.; Carrasco-Gallego, R. Conceptualizing the sharing economy through presenting a comprehensive framework. Sustainability 2018, 10, 2336. [CrossRef]

148. LLP. The Sharing Economy; PricewaterhouseCoopers LLP: New York, NY, USA, 2015.

149. Simanis, E.; Hart, S. Innovation from the inside out. Available online: https:/ / sloanreview.mit.edu (accessed on 26 November 2018).

150. Gupta, S. Driving Digital Strategy: A Guide to Reimagining Your Business; Harvard Business Review Press: Boston, MA, USA, 2018; p. 288.

151. McKinsey. Ge's jeff immelt on digitizing in the industrial space. Available online: https: / / www.mckinsey.com/business-functions/organization/our-insights / ges-jeff-immelt-on-digitizing-inthe-industrial-space (accessed on 26 November 2018).

152. Brown, B.; Gottlieb, J. The need to lead in data and analytics. Available online: https://www.mckinsey.com/ business-functions / digital-mckinsey/our-insights/the-need-to-lead-in-data-and-analytics (accessed on 26 November 2018).

153. Zheng, W.; Yang, B.; McLean, G.N. Linking organizational culture, structure, strategy, and organizational effectiveness: Mediating role of knowledge management. J. Bus. Res. 2010, 63, 763-771. [CrossRef]

154. Digitizing the Value Chain for High Performance. In Accenture Consulting, Technology, Outsourcing. Available online: https://www.accenture.com/us-en/ \{\}/media/Accenture/Conversion-Assets/DotCom/ Documents/Global/PDF/Strategy_3/Accenture-Digitizing-the-Value-Chain-for-High-Performance.pdf (accessed on 26 November 2018).

155. Porter, M.E. Competitive Advantage: Creating and Sustaining Superior Performance; Free Press: New York, NY, USA, 1985; p. 214.

156. Xiao, B.; Benbasat, I. E-commerce product recommendation agents: Use, characteristics, and impact. MIS Q. 2007, 31, 137-209. [CrossRef]

157. Deterding, S.; Dixon, D.; Khaled, R.; Nacke, L. From Game Design Elements to Gamefulness: Defining Gamification. In Proceedings of the 15th International Academic MindTrek Conference: Envisioning Future Media Environments, Tampere, Finland, 28-30 September 2011; pp. 9-15.

158. Berman, B. 3-D printing: The new industrial revolution. Bus. Horizons 2012, 55, 155-162. [CrossRef]

159. Huston, L.; Sakkab, N. Connect and develop: Inside procter \& gamble's new model for innovation. Harv. Bus. Rev. 2006, 84, 58-66.

160. Helser, M. The future of open innovation. Res. Technol. Manag. 2017. [CrossRef]

161. Kreuzer, U. Defects: A vanishing species? Pictures of the Future: The Magazine for Research and Innovation, Siemens, October 2014.

162. Lakhani, K.R.; Iansiti, M.; Herman, K. Ge and the Industrial Internet; Harvard Business School: Boston, MA, USA, 2014.

163. Gubbi, J.; Buyya, R.; Marusic, S.; Palaniswami, M. Internet of things (IOT): A vision, architectural elements, and future directions. Future Gener. Comput. Syst. 2013, 29, 1645-1660. [CrossRef]

164. Seuring, S.; Müller, M. From a literature review to a conceptual framework for sustainable supply chain management. J. Clean. Prod. 2008, 16, 1699-1710. [CrossRef]

165. Paper, T.W. Demand Planning-The Catalyst for Higher Performance. Available online: https://www.tecsys. com/webinar/demand-planning-performance/ (accessed on 26 November 2018).

166. Aronow, S.; Ennis, K.; Romano, J. The Gartner Supply Chain Top 25 for 2017. Available online: https: / / www.gartner.com/doc/3728317/gartner-supply-chain-top- (accessed on 26 November 2018).

167. Doz, Y.L.; Kosonen, M. Embedding strategic agility: A leadership agenda for accelerating business model renewal. Long Range Plan. 2010, 43, 370-382. [CrossRef]

168. Immelt, J.R. How I remade Ge and what I learnded along the way. Harv. Bus. Rev. 2017, 95, 42-51.

169. Kotter, J.P. Leading change: Why transformation efforts fail. Harv. Bus. Rev. 1995, 73, 59-67.

170. Kotter, J.P. Leading Change; Harvard Business Press: Brighton, MA, USA, 1996.

171. El Sawy, O.A.; Kræmmergaard, P.; Amsinck, H.; Vinther, A.L. How LEGO built the foundations and enterprise capabilities for digital leadership. MIS Q. Exec. 2016, 15, 141-166.

172. Björkdahl, J. Technology cross-fertilization and the business model: The case of integrating icts in mechanical engineering products. Res. Policy 2009, 38, 1468-1477. [CrossRef] 
173. Hienerth, C.; Keinz, P.; Lettl, C. Exploring the nature and implementation process of user-centric business models. Long Range Plan. 2011, 44, 344-374. [CrossRef]

174. Zott, C.; Amit, R. Business model innovation: How to create value in a digital world. GfK-Mark. Intell. Rev. 2017, 9, 19-23. [CrossRef]

175. Hacklin, F.; Björkdahl, J.; Wallin, M.W. Strategies for business model innovation: How firms reel in migrating value. Long Range Plan. 2018, 51, 82-110. [CrossRef]

176. Scholz, R.W.; Steiner, G. The real type and ideal type of transdisciplinary processes: Part I-Theoretical foundations. Sustain. Sci. 2015, 10, 527-544. [CrossRef]

177. Scholz, R.W.; Steiner, G. Transdisciplinarity at the crossroads. Sustain. Sci. 2015, 10, 521-526. [CrossRef]

178. Gibbons, M.; Limoges, C.; Nowotny, H.; Schwartzmann, S.; Scott, P.; Trow, M. The New Production of Knowledge: The Dynamics of Science and Research in Contemporary Societies; Sage: London, UK, 1994.

2018 by the author. Licensee MDPI, Basel, Switzerland. This article is an open access article distributed under the terms and conditions of the Creative Commons Attribution (CC BY) license (http://creativecommons.org/licenses/by/4.0/). 